\title{
Thomas More's Utopia: Preface to Reformation
}

WALTER M. GORDON

Summary: Recent studies have stressed the ambiguity of Thomas More's Utopia. Although the essay does not argue against this view, it does point to the clear and basic contention of the work which, if lost, makes it impossible to come to grips with the questions the book poses. Utopia criticizes the upper, not the lower class and leans towards moral reform, but with an incertitude concerning the externals of this sorely needed change. As such it anticipates Reformation.

Two recent books on More's Utopia confirm the present critical trend of stressing the author's unwillingness to offer us answers to all the questions which the work raises. Dominic Baker-Smith in More's Utopia concludes his learned investigation by deferring to the judgment of the interpreters writing during the last two decades: "A striking feature," he writes, "in recent studies, notably those by Skinner or Logan, or the articles by Fenlon and Bradshaw, is their general recognition ... of a sphinx-like ambiguity over the actual possibilities of human society which compels the reader to shoulder the burden of interpretation."1 In Utopia: An Elusive Vision, Alistair Fox is even more outspoken than Baker-Smith: “... More relegates the chance of ever pinning down the truth about Utopia to the realms of impossibility. ..."2 Given the political nature of the work and the dialectical quality of the author's genius, we could hardly expect him to force an answer upon us in a book which so deftly captures the problems of constructing an ideal society from the ground up. Still, the objection of Lyman Tower Sargent to what he would call the obscurantist views of the 
scholars should not pass unnoticed. "Recent More scholarship," he holds, "makes the Utopia an interesting puzzle but deprives it of interest to anyone but a More scholar. Taken more or less at face value, Utopia is an important work in the history of political thought. As a puzzle, Utopia has no such importance." 3 Why a book should be dismissed because it engages the mind with social complexities is not explained by Sargent. His impatience with the critics probably stems from their failure to cast light on the work as a whole, but a simple answer, I fear, would do nothing but distort both the problematic subject of which More writes and the author's own capacity to represent the give-and-take of intellectual encounters.

I have stated elsewhere that More may have put together the best collection of dialogues in the entire field of English letters, which suggests that he favors a literature of free argumentation rather than a line of prose culminating in settled clarity. ${ }^{4}$ All the same, Sargent's complaint about the commentaries on the Utopia appears valid enough if the critical assessment of it sacrifices the more evident concerns of the work to an overwhelming cloud of perplexity and doubt. Even if we cannot summon to our seat of judgment a single essay which errs by creating complications that do not exist, it may prove helpful, given the current rage for incertitude, to adopt an approach to the Utopia that calls to mind those aspects of the author's undertaking that he wants to make clear. A hint regarding what that approach might be is given by Dermot Fenlon in his "England and Europe: Utopia and Its Aftermath" where he succinctly expresses the main intent of his article. "Here then," he writes, "is the heart of my hypothesis: the urge to transform monastic values into the virtues appropriate to the lay state, locates the appeal of Utopia within a common point of departure leading to the Reformation fashioned at Calvin's Geneva and the Counter Reformation in the Church of Rome." 5 Fenlon sets out to ascertain "the significance of Utopia at the time of its publication." He desires to know the meaning of Utopia both "for More himself" and "for the European reading public which first received it," and, in particular, he is looking for "the connection between the issues which it explored and the issues which helped, within a year of its appearance, to precipitate the Protestant Reformation."6 Fenlon pays no attention to the work's relationship with either its medieval past or its distant future; he concentrates on the period in which it was composed and on the hopes and the fears of the religious minds contemporary to More. Something was alive in the air to which men like Luther and Zwingli and Müntzer were reacting, and, even if they all responded differently, each man had concerns that are 
anticipated in the Utopia, and this community of interest can be made manifest without doing violence to More's text. Here, at least, is the starting point which can serve to quiet those readers like Sargent, who become angry with the current inclination of scholars to fix upon the final impenetrability of the work's utterance.

Just what is the amibiguity that our scholars have insisted upon in their reading of Utopia? It centers on the difference between the authoritative Raphael Hythloday and the hesitant Thomas Morus in the respective ways they react to the phenomenon of the island republic. The first of these characters supports the Utopian constitution with an unquestioning approval; the second is not nearly so sanguine about installing Utopian social life upon European ground. So the problem of comprehending what the author has in mind is referred back to the reader. The question he must struggle with is put precisely by Baker-Smith: "How far can the ideal be known, known not simply as an object of intellectual contemplation but as an operative principle?"7 Whatever the Utopia contains by way of a direct appeal to action that goes beyond mere contemplation will be decided, as was hinted above, by its relevance to the context of reform in which it was written. If we are to affirm that the book is, among other things, a document calling for change at any level, we will have to show that at least this part of its meaning is clear enough to yield readily to our understanding.

To test the power of Utopia as a work which beckons its readers to reform their lives, a threefold investigation will be followed. First, a negative element must be identified in the text, a failure on the part of Christian leaders to realize anything approaching the kind of life which Christ demanded of those who would be one with him. At this initial stage, the main interest will be placed upon the object of Utopian satire. The second phase of this study will concentrate upon the figure of Raphael Hythloday as prophet or the one who would lay waste and build. ${ }^{8}$ Even if we concede that the character does not enjoy the final word in the debate between himself and Morus, his commanding presence within the action and his indignation over the abuses perpetuated by the kings and their noble associates must not pass unnoticed. Finally, it must be determined whether anything of a positive nature issues from the attack on social malevolence made clear by the satire and the lofty resentment of Raphael. The answer to this last enquiry will depend largely upon the interpretation given to the author's depiction of Utopia's social and cultural makeup. Does some aspect or feature of major importance on this mysterious island cry out for implementation? 
Morean satire leaves the common folk virtually untouched because the full weight of its attack falls upon the privileged class. The author sows contempt for the rulers of Europe, both secular and religious, and has nothing good to say about the nobility in general. Be they at work or at play, he reveals his scorn for their habitual self-indulgence, pursued always at the expense of the less fortunate. Book One twice takes us behind the closed doors of the royal council chamber where the king and his advisers sit in conference. The reader is asked to imagine a meeting of the French directors of state who urge the monarch to follow every opportunity leading to the enlargement of both his territories and his renown. Hythloday sees himself at such a session pleading the cause of restraint to no avail. The inexhaustible appetite for more land so dominates the scene that Raphael's contribution to it becomes meaningless, almost laughable. The camera moves from France to a similar gathering in a land without a name. There the consultants to the king are all intent upon bleeding the populace of its money in order to line both the royal coffers and the nobility's pockets. The denizens of such places are later referred to in the text as madmen. ${ }^{9}$ So much for the nobility at work.

When the same class turns to play, its festivities are written off as time-serving enterprises that stray far from the sane enjoyment of true entertainment. In its hours of relaxation, the nobility cannot cast off the compulsive drive to impress the ruler of the court. The scene at the Lambeth banquet, presided over by Cardinal Morton, depicts the anonymous aristocrats seated at table and awaiting their cue from the prelate, a cue which will determine their reaction to Hythloday's argument (p. 83). When, in Book Two, Raphael discourses upon the unnatural and inhumane pleasures to be gotten from the hunt, the reader is almost certain to recall that such is the pastime which fills the leisure hours of the nobility. The chase provides the members of the warrior class with the conditioning necessary to keep them fit for battle. It readies them for military ventures in more ways than one. It not only demands energetic horsemanship from the hunter but also maintains his appetite for blood-letting. In this regard, Hexter contrasts the English nobleman, mounted on his steed, with the citizen of Utopia who reveals a greater sensitivity to the pain and suffering of an animal. "In Utopia," he writes, "the butchery of animals, whether in the fields or in the shambles, is the work for slaves; freemen do not engage in it lest it dull in them the quality of mercy. ... Yet to enjoy such brutalizing sports the English aristocrats drive their poor tenants off the land in order to make game preserves." 10 
When the nobility is summoned to appear in the parades similar to the spectacle of the royal progress, the participants try their very best to overawe the crowd of people who line the roadway in order to behold the show. An amusing scene is drawn by More when he recounts the solemn entry of the Anemolian ambassadors into Utopia. We are told that the leading figures in this legation, being all noblemen, wanted to be outfitted in their finest array, resplendent with gold decorations. "Being more proud than wise," the narrator observes, "they determined by the grandeur of their apparel to represent the gods themselves (deos quosdam representare) and by their splendid adornment to dazzle the eyes of the poor Utopians" (p. 155). Needless to say, these members of the nobility, decked out in their ornate costumes, failed to win the recognition that they believed their exotic clothes would bring them. Not knowing any better because of their total ignorance of Utopian attitudes and education, they were taken to be the slaves of their more simply dressed attendants.

The Utopia shows about as much esteem for the European monarch as it does for the nobility. We look in vain for any sign of a king within the governing structure of More's ideal republic. He has vanished completely from the political scene along with his noble retinue. Of course, the sovereign occupies a significant part of the discussion in Book One when the dialogue turns to the treatment of abuses. The royal presence, however, is meant to draw sometimes laughter and sometimes scorn from the reader. A motion put forward by a member of the French council indicates a tone of mockery directed at the Roman emperor himself. While other advisors urge the king to extend his territory, this shrewd observer introduces a proposal for lulling the emperor to sleep while France helps herself to the lands of her weaker neighbors. He recommends that "the sacred power of his imperial majesty be propitiated with a gift of gold, as it were, in the form of a holy offering."11 The irony of this passage rests upon a choice of words associated with an act of sacrifice made at the altar of a church or a temple. The emperor has been singled out as the object of a worship normally accorded to the deity alone. Imperial pomp has done its work when it impresses upon the minds of its beholders a godliness that solicits adoration. Of course, as the emperor is flattered by this masque of devotion, the Morean irony invites us to laugh at such pretense.

When kings and nobles fall victim to Morean satire, we cannot expect their spiritual equivalents to remain unscathed. In one sense, the author's belief in the church saves the churchmen from the bitter assault directed at 
the secular aristocrats; in another sense, the betrayal of their own high calling demands that the author speak out against the delinquent ecclesiastics. The reverend abbots are listed among the wealthy landowners who banish their tenants from the fields and farms they had been tending. Hythloday lumps these high ranking clergymen with the nobility; one order of the elite stands as guilty as the other (p. 67). At the table of Cardinal Morton, the friars are laughingly associated with the vagrants and tramps of England (p. 83). When Hythloday mentions the high percentage of the Utopian populace that belongs to the labor force, he cannot resist comparing it with the very low proportion of workers found in the European communities where so many of its inhabitants are exempted from the menial occupations upon which society depends. "Besides," he observes, "how great and how lazy is the crowd of priests and so-called religious" (p. 131). Here, the clergy are simply written off as do-nothings. A sharper rebuke is reserved for the supreme pontiff in his dealings with other countries within Christendom. More makes the office of the pope the chief target of an ironic passage which praises Christian nations for their so-called rectitude in holding to the treaties they sign. The supreme pontiffs set the example in this matter. "Popes are perfectly right," he says, "... in thinking it a most disgraceful thing that those who are specially called the faithful should not faithfully adhere to their commitments" (p. 197). The Latin text in this sentence plays upon the cognates fides and fideles in an ironic reference to the high priest of Christendom, the great keeper of the faith, who cares so little about keeping his word. The author shows us a pope become indignant because the fideles should be so wanting in their fides, when he himself, unfaithful and untrustworthy, is without doubt the greatest offender of all.

We turn now from Morean satire to the second part of this investigation: Raphael Hythloday's denunciation of Western political attitudes. As long as this prophetlike figure is being used in the service of the author's satirical intentions, we feel he is not, in all of these cases, speaking in his own voice. In the passage just cited on the pope's handling of treaties, for instance, a case can be made for Raphael's simple affirmation of the papal integrity in such business, while the reader is left to determine the extent of the irony, about which the speaker need not even be aware. In other words, irony can be attributed to the author's mind without insisting upon the persona's participation in it. Towards the close of the first book of Utopia, Hythloday condemns the dissembling of the doctrine of Christ and calls attention to the gospel command to preach these same teachings "openly from the 
housetops" (p. 101). Direct, unvarnished address, without the least hint of irony, characterizes Raphael's speech, and nowhere is he more himself than in the peroration to his description of Utopian life.

Here Hythloday presents us with his parting words; after the conclusion of this passage, we do not hear from him again. Now he assumes the full stature of his role as prophet and cries out, to the top of his bent, words of disdain and anger with a majestic power which the author will not achieve in the vast bulk of polemical literature he will later compose at the expense of the heretics. The zeal of Raphael attains a spellbinding force that More will never again be able to muster. A spirit seems to take hold of him as he delivers his tribute to the republic which has for him successfully established the best of all possible governments by means of a social structure that does away with the least trace of a privileged class. When Hythloday compares the accomplishments of this island people with the record of corruption found in Europe, the ruling classes of Christendom are laid waste by a most destructive analysis of the uses to which they have applied their political devices. They have simply created a world to accommodate the wealthy in their pursuit of happiness, and they have secured their own position of dominance by further impoverishing the people who possess little or nothing:

... the rich every day extort a part of their daily allowance from the poor not only by private fraud but by public law. Even before they did so it seemed unjust that persons deserving best of the commonwealth should have the worst return. Now they have further distorted and debased the right and, finally, by making laws, have palmed it off as justice. Consequently, when I consider and turn over in my mind the state of all commonwealths flourishing anywhere today, so help me God, I can see nothing else than a kind of conspiracy of the rich, who are aiming at their own interests under the name and title of the commonwealth (p. 241).

This caustic statement denounces with a burning antagonism the classes whose score against the poor has been settled by laws passed off in the name of justice. Raphael's words show little or no regard for a political hierarchy that wills a state of fixity upon the haves and have-nots as if nature herself had ordered people to remain within the level of development and comfort in which they find themselves.

Hythloday touches on the perverse aspect of those who seek selfgratification at another's expense when he makes one final assault on pride as the great enemy to the well-being of the human community. "Pride," he declares, "measures prosperity not by her own advantages but by others' 
disadvantages. Pride would not consent to be made even a goddess if no poor wretches were left for her to domineer over and scoff at, if her good fortune might not dazzle by comparison with their miseries, if the display of her riches did not torment and intensify their poverty. This serpent from hell entwines itself around the hearts of men and acts like a suckfish in preventing and hindering them from entering on a better way of life" (pp. 243-245).

The images of the serpent and the suckfish in the final sentence of this passage indicate an ironic twist in Hythloday's account of his explorations. Early in Book One we are told that Morus and Giles, in their desire to hear about real voyages and not those much-proliferated travel tales of antiquity, were not disposed to listen to purely fictitious confrontations with outlandish beasts. "Scyllas and greedy Celaenos," Morus humorously notes, "and folk-devouring Laestrygones and similar frightful monsters are common enough, but well and wisely trained citizens are not every where to be found" (p. 53). The listeners to Raphael's narrative do not want to be bored by the unbelievable creatures so often used to enhance the adventures of the raconteur. Not long after we are told what Morus and Giles hope to hear, Hythloday, knowingly or not, defies the expectations of his listeners by recounting just such an incident but in a manner which does not even begin to demand the least bit of the credulity from his two acquaintances. He refers, surprisingly enough, to the sheep grazing the English countryside which have become "so greedy and wild that they devour human beings themselves and devastate and depopulate fields, houses, and towns" (pp. 65-67). The mild flock has taken on the characteristics of a stampeding herd capable of laying waste farmland and municipality. Of course, the violence in this picture is meant to be traced from the beasts to the more beastly owners: the noblemen, the gentlemen, and the abbots who have turned "all human habitations and all cultivated land into a wilderness" (p. 67). Raphael's account, then, does not ignore the presence of a monster threatening human life; rather it relocates the predator by removing it from the realm of fantasy and situating it where it has always thrived. He sees all too clearly that a "serpent from hell entwines itself around the hearts of men" (p. 243). The transmigration of the dragon from the primal forest to a place in the human breast also evokes the notion of a changed field of combat, the location which the Utopia sees as the arena for contention and reform.

If Hythloday is summoning his audience to battle, it is not against the dragon of mythology but rather against the deranged forces driving the human heart. There is no need to look around for a St. George or a chivalric 
horseman to do man's fighting for him. Rather the noble descendants of the warrior knights are being asked to cast off their tendencies towards heroic display and to undertake a more challenging and pertinent battle against their own unruly persons. This would appear to be part of what Hythloday, the prophet, cries out for at the end of the work, but we know that Hythloday is not necessarily the spokesperson for the author and that others have been led astray by identifying with this stern character in the attempt to stabilize the meaning of the text. We must pass, then, to a reading that takes into account all the elements of the book, howsoever disparate they may seem. The real difficulty lies not in the intensity of Raphael's attack on the nobility but rather in his unconditional affirmation of the Utopian way of life. How, in the author's mind, are we meant to understand such an attitude? This query brings us to the final stage of our investigation into Utopia as a document calling for reformation.

If we are to understand Hythloday as he appears in the Utopia, we cannot afford to forget the etymology of the name which means "expert in trifles" or "well-learned in nonsense." 12 The author warns us through is wordplay that the character is not to be taken in a simple, straightforward manner. Consider also the very foundation of his argument. He refuses adamantly to engage in politics where the government has not espoused a communist ideal similar to that which obtains in Utopia. When, in the first book, Morus tells him that such an arrangement would not work, Raphael refutes him by appealing to his island republic. Literally, communism has brought justice and relief to humankind in a land that is called "Nowhere." Both the significance of his name and the translation of the word indicating the place where his dream has been realized tend to repulse the thrust of his reasoning. On the other hand, no other pages in the book are endowed with such power as those few leaves where Hythloday makes the final appeal to his listeners. Thomas More, in this passage, confers upon his singularly mysterious persona an eloquence that lifts his language beyond the reach of any other character in the story. It would appear that the reader is being asked to reduce to a unified cogency this personage who, at one moment, is called a fool, and, at another, scatters to the winds the mockery directed at him by means of the sheer force of his speech.

I believe that Raphael's last words to us must first be related to Morus' reaction to the narrator's entire account of Utopia. The enthusiasm, so evident in Hythloday with regard to the place he has been describing is certainly not reflected in Morus as he assesses what he has heard. He 
dismisses many things about the country as "very absurdly established." These customs and laws of ridiculous origin include "their method of waging war, their ceremonies and religion, as well as their other institutions." He then singles out as most foolish "that feature which is the principal foundation of their whole structure. I mean their common life and subsistence without any exchange of money. This latter alone utterly overthrows all the nobility, magnificence, splendor, and majesty which are, in the estimation of the common people, the true glories and ornaments of the commonwealth" (p. 245). Morus lays stress upon the underlying absurdity of Utopia: it undermines those features which the multitude believes to be the very glories and ornaments of society. In other words, the Utopian republic has made the foolish error of basing its structure upon the political insight that nobility, magnificence, splendor, and majesty are empty of any real social weight. They function, to borrow from the language of Erasmus, like reversed Sileni which captivate the fancy of the vulgar mind whose judgment is limited by the physical makeup, the mere surface of things. Erasmus, in his essay on the Sileni Alcibiadis, urges the beholder to take heed of the possibility that truth is not always apprehended at first glance. The magnificence with which the royal prince surrounds himself invites the beholder to regard him "like a god on earth," but, when this reversed Silenus is opened, the onlooker discovers "the enemy of his people, a hater of the public peace, a sower of discord. ..."13 The irony present in Morus' description of the popular mentality at the end of the Utopia epitomizes the same habit of thought we see developed here by Erasmus. What appears to be noble and majestic, in his treatment of the subject, turns out to be abject and brutal.

Erasmus' discourse on the Sileni Alcibiadis, as well as suggesting a manner of understanding the great spectacles of life which, under the guise of play or pastime, are most seriously involved with the manifestation of power, also provides guidance to a reader wanting to make sense of the final pages of Utopia. The Sileni, in their proper meaning, stand in opposition to the reversed Sileni, which project an impression of magnificence only to be proven vile and despicable. The true Sileni, once their secret has been discovered, provide for us a more pleasant surprise. When the ridiculouslooking doll is opened, there appears "the figure of a god, so that the amusing depiction would show off the art of the carver." 14 To this statuette Erasmus compares the person of Socrates. At first look, the man strikes us with his ludicrous, bovine face, but, when we open this Silenus, we see revealed a noble soul rising above insult, bad fortune, and death. Finally, the habit of 
mind that pierces below the surface is applied to holy scripture where the letter of the text, which at times may seem incongruous, can yield a profound wisdom if scrutinized in depth.

In the Sileni Alcibiadis, Erasmus entertains within the play of his mind a critical theory that pertains to the reading of literary works. It offers an approach to a text that has a semblance of the ridiculous about it but which cannot necessarily be disregarded on that score. Notice that Morus, in his final evaluation of the Utopian arrangement of society, dismisses much of it as "very absurdly established." Yet, in the very same breath, he blames the Utopian for discarding nobility and magnificence, the very elements which the entire book has been satirizing. ${ }^{15}$ Is it possible that Utopia, despite its ludicrous polity, has something to offer us? It may be that all of its external order, the common dress, the common meals, the common life shared together are surface realities which must be penetrated if the reader is to discover the true meaning of the work. Like the Sileni in Erasmus' essay, the image that we view must be opened as was the doll in order to arrive at its wealth. This would mean that the island is not promoting itself as a model for mankind to imitate but rather hides within its confines values for the reader to seize upon if society is to undergo the transformation that the times are demanding.

In the Erasmian application of the Silenus image to characters borrowed from history, the looks and dress of the person do not at all correspond to "what he conceals in his soul." 16 A similar contrast exists between the letter of the scriptures and their spiritual meaning: at the surface we may encounter "Adam being made from mud, ... God walking in the cool of the day, the sword set at the gates of Paradise" as if the narration had been fashioned in Homer's workshop. "And yet under these veils ... what wonderful wisdom lies hidden!" As in the Old Testament, so in the New: the shell must be opened in order to find inside "that profound wisdom, truly divine, a touch of something which is clearly like Christ himself." 17 We must now ask ourselves whether or not Utopia leads itself to a reading similar to Erasmus' interpretation of the scriptures. If it does, we will have to avoid a literal assessment of the place and look beyond the facade in search of a truth which the houses and the dress of these islanders serve both to hide and to reveal.

Let us begin with the unlocked doors. ${ }^{18}$ These will only prove to be an introduction to chaos if adopted by a society that has already become acquisitive. But does the Utopian doorway function merely as a suggestion for European home construction or does the disdain for locks exist to 
engender a frame of mind? Likewise, the chamberpot made of gold does not serve as a practical household arrangement but falls into place only when recognizing one's scale of values. Both the unlocked doors and the uses to which gold is put invite a non-literal, non-pragmatic interpretation. The meaning of Utopia lies beneath its surface, behind its letter. If then the externals of Hythloday's description are better read as guideposts to an inner significance, we might come closer to the secret of the text by focusing upon the interior life of the Utopians themselves. Even here we first notice a seemingly foolish and inappropriate mentality attributed to a people committed to sharing its wealth together. Their philosophy singles out as its principle and foundation neither a stoical self-discipline nor an ascetical disdain for the goods of this life. The Utopians live for pleasure and thus embrace an epicureanism in some shape or form. It may well be that the paradox central to the entire work lies within this distinctly Utopian kind of pleasure-seeking.

To begin with, More employs voluptas as the word signifying the kind of pleasure that the Utopians live for. As they account for this particular inclination of soul, they see it tending the natural tendency towards physical and mental satisfaction. "By pleasure they understand every movement and state of body or mind in which, under the guidance of nature, man delights to dwell" (p. 167). The author has taken care not to remove the corporeal aspect from the pleasure in question. By avoiding the simple identification of this conflict with the very highest reaches of human satisfaction, More makes certain that the enjoyment under discussion in this part of the book cannot simply be relegated to an afterlife. The pleasure for which the Utopians live must include the rewards expected from the toil of this present existence; otherwise, their whole teaching in this matter might make them susceptible to a promise of a blessed happiness after death which they could accept in exchange for a life of drudgery and subjection upon earth. Thus these people might become serviceable to a tyrant who would willingly destroy the egalitarian structure of their republic.

Of course, to say that the Utopians live for pleasure does not mean that they have delivered themselves over to the indulgence of their appetites. They are not epicures in this sense. Rather, their notion of delight has a necessary social orientation about it. They do not live to soak up as much personal comfort as possible. This would characterize their pursuit of pleasure as merely private, without any awareness that the good things to be enjoyed by the community are destined to be shared and not simply ap- 
propriated as one's own. In other words, the scope of their pleasure-seeking extends into pleasure-making. At this point, we begin to appreciate the religious aspect of their epicurean thought. Hythloday tells us that the Utopians "never have a discussion of philosophy without uniting certain principles taken from religion as well. ..." (p. 161). The author, through the voice of the narrator, introduces the exposition of the philosophy of pleasure with a preamble stating that the account will draw upon Utopian religious beliefs as they are joined in their own reflection upon the human condition. They maintain that "nature calls all men to help one another to a merrier life" out of a sound consideration: "for no one is raised so far above the common lot of mankind as to have his sole person the object of nature's care" (p. 165). These words imply the critique of the notion, cherished by the upper strata of European society, that the state cannot exist without its privileged class, with its privileged wealth and ease, and, if the aristocracy is being challenged here, we have no reason for thinking that the monarchy is exempt from such an attack. In opposition to the exclusivist prejudices of such people, nature beckons humankind away from the error of making too much of any one social group when she "equally favors all whom she endows with the same form" (p. 165).

This passage makes it very clear that Utopian equality is based upon a conviction that takes its strength from both philosophy and religion. Observation of their own species forces the Utopians to conclude that all people are fundamentally the same. Nature herself plays no favorites but, as it were, loves all whom she embraces in the communion of a single form, "quos eiusdem formae communionem complectitur" (p. 164). Because these people attribute "both the creation and the providential government of the whole world" to one supreme being, then nature, in this context, must be grasped as carrying out the will of God, and the communio formae with which she endows humanity becomes the necessary guide to ethical conduct (p. 217). "Consequently nature surely bids you take constant care not so to further your own advantages as to cause disadvantages to your fellows" (p. 165). On the one hand, cool, honest reasoning leads to the inescapable conclusion that the species is one; on the other hand, the communion of those participating in the same form leads to a belief that all are entitled to share in the good things of creation as a manner of fulfilling the design of God's providence.

The wisdom of Utopia lies neither in its laws or customs nor in its moneyless economy but rather in the aspiration of the nation as a whole as these desires are reflected in their epicurean philosophy. The Utopians make 
much of the good things life has to offer, and they see them as a gift of providence to that entire country. This republic may first strike us as the answer to Erasmus' idealistic question: "What else is a city but a great monastery?"19 Fenlon simply dismisses the suggestion when used as the key into More's imagined society. "More wrote Utopia," according to Fenlon, "because he was acutely aware that it was impossible to translate the monastic principle ... into public life." ${ }^{20}$ Surely More has no intention of reordering people within the narrow confines of a monastic rule. Still, such an outlandish projection can be read as a Silenus, absurd in itself, but both hiding and revealing a greater happiness for the whole of humanity. Could not the complete picture of Utopian life be leading to the truth, veiled within its paradoxical philosophy of pleasure, that no personal advantage is to be procured at the expense of others because we are led by nature herself to share the blessings of providence with one another as a community?

The tension that exists in the Utopia is not found first and foremost in the differences between Morus and Hythloday over the question of political involvement. The real conflict of the book pits private interest against the public well-being. This might be called the timeless contest because it is discovered by Augustine in the heart of Satan at the moment of his fall. The first evil act as understood within the Christian tradition is put in terms of the clash between private and public concerns. "Where pride desires to stand out," Augustine writes, "there it is thrust into the narrowness of want as it reduces a concern for all to its own interest out of a self-defeating love."21 This mentality which characterizes the first sin reappears in More's delineation of the evil that undermines society in general: "Everyone loves his own premises, his own money; everyone is interested in his own profession, or his own corporation; anything at all which we can call our own attracts our attentions to itself and away from common interests." 22 More, in one sense, is calling a particular monk back to a spirit peculiar to monasticism, but the full import of what he says there reaches beyond the abbey back to creation itself and then to the beginnings of Christianity. He holds that God, in his providence, established all the good things of his making for all people ("cum omnia institueret communia") and that Christ "endeavored to urge men to turn away from provincial interests ("a privato") back to universal interests ("in commune")." 23 Once again we encounter a tension arising between private concerns and those involved with the commonwealth. Utopia means to break the stranglehold which personal preoccupation has upon the community, and it directs its most passionate assertions against an aristocracy 
deadened by its self-satisfaction. More had the learned and the powerful in mind when he put his Utopia together. His choice of Latin as the means of communicating his thought indicates that he is not addressing the poor and the oppressed, and, when he admits, in a letter to a courtier, that he intended to betroth his Utopia "to Cardinal Wolsey alone," we have no reason to seek further for the kind of reader More had in mind as he composed the book. ${ }^{24}$

So just what does More leave unsettled and what is made clear on the last pages of his text? His evaluation of the Utopian model remains obscure by reason of the ironic and indecisive utterances of Thomas Morus, the dramatis persona. Hythloday is ushered into dinner as a troubled and troubling figure whom neither Giles nor Morus wish to engage in further debate. His diatribe against the conspiracy of the rich continues to echo in the reader's mind and warns the other two personae against challenging such a denunciation because its rebuttal is virtually impossible. More, the author, has called for the reform of Christendom not by urging upon the reading audience the destruction of the papacy, or the monarchy, or the nobility. Even if Hythloday would destroy all privilege, his Utopia does not provide a workable solution to the problem. Nothing remains but to take to heart the evil which self-interest works upon the community and allow the mind to deliver itself to the quest for new lands where the Utopian ideal can be nourished with less rigor and absurdity.

Other programs for social revitalization were spawned during the Renaissance period. Some of them did not live long, and others, having served their purpose, now seem less relevant than More's unsettling book. Bacon's New Atlantis impresses us as more prophetic than the Utopia, but for this very reason, it has less to tell us today. Its technological prophecy is spent; nor is Utopia's own future assured. Its exhortation to a fresh commitment relies upon the acknowledgement of a creation and a belief in the validity of a concept of living which leaves no room for privilege. If later in his career More seems to have been embarrassed by his little classic, the cause for that disturbance might be traced to the fact that the Utopia was no longer being understood as a plea for unity. ${ }^{25}$ More does not escape at least part of the blame here. Hythloday betrays an inclination towards rebellion, and his insistence upon change has been judiciously described as bristling "with metaphors of deracination and eradication." 26 More's own creation, his most challenging character, belongs to a line of prophetic voices in that he echoes the outcry of a Savonarola and anticipates the anger of a Thomas Müntzer. Religious zeal is as difficult to control as it is to ignore. Thomas 
More appears to have experienced these very problems in bringing Raphael Hythloday to life. He describes the trouble with Utopia at the time of the Reformation in terms of a misunderstanding. ${ }^{27}$ No doubt the author had hoped for the birth of a new sense of religious unity. But it is equally certain that the Utopia, through its plea for reform, acts paradoxically as a herald to the Reformation in its full historical sense when it summons to life the isolated and indignant figure of Raphael Hythloday.

University of Georgia

\section{Notes}

1. (London: Harper Collins Academic, 1991), p. 243. The author in his bibliography gives full reference to the studies by Skinner and Logan and the articles by Fenlon and Bradshaw. George M. Logan, in his "Interpreting Utopia: Ten Recent Studies and the Modern Critical Traditions" (Moreana, 31 [June, 1994], 203-258), presents a concise review of investigations into More's Utopia made between 1987 and 1993.

2. (New York: Twayne, 1993), p. 105.

3. “More's Utopia: An Interpretation of Its Social Theory," History of Political Thought, 5, 2 (Summer, 1984), p. 210.

4. Walter M. Gordon, “The Platonic Dramaturgy of Thomas More's Dialogues," Journal of Medieval and Renaissance Studies, 8, 2 (Fall, 1978), 193-215.

5. Transactions of the Royal Historical Society, Fifth Series, 25 (1975), p. 131.

6. Fenlon, Art. cit., pp. 116-118.

7. Baker-Smith, Op. cit., p. 201.

8. At the beginning of Jeremiah, Yahweh summons the prophet both to destroy and to restore (I:10).

9. Hythloday, in refusing to accommodate himself to these sycophant courtiers, claims that such conformity with "the madness of others" would inevitably lead to the same lunacy in himself. See Utopia, ed. Edward Surtz and J. H. Hexter (New Haven: Yale University Press, 1965), p. 101. Unless otherwise indicated, all further citations of the Utopia will be made from this edition and the page references will be included in the text.

10. Hexter, introduction to Utopia, p. lii.

11. I have supplied my own translation here. The rendering of this sentence in the Yale text (p. 89 ) misses the religious overtones in the original Latin.

12. Utopia, p. 301.

13. Margaret Mann Philips, The "Adages" of Erasmus: A Study with Translations (Cambridge: Cambridge University Press, 1964), p. 276, herefter cited as Adages.

14. Adages, p. 269. 
15. In his introduction to the Yale edition of Utopia, Edward Surtz singles this passage out as the "finest and most effective instance of irony" in the work (p. clii).

16. Adages, p. 269.

17. Adages, pp. 275-276.

18. The folding doors of all Utopian houses are "easily opened by hand" and "give admission to anyone" (p. 121).

19. Letter to Paul Volz (Allen, Ep. 858). I quote from John C. Olin's translation as it appears on page 130 of his Desiderius Erasmus: Christian Humanism and the Reformation (New York: Harper and Row, 1965).

20. Fenlon, Art. cit., p. 125.

21. "Unde itaque vult eminere superbia inde in angustias egestatemque contruditur, cum ex commune ad proprium damnoso sui amore redigitur." De genesi ad literam, 11:15. PL 34, pp. 436-437.

22. St. Thomas More: Selected Letters, ed. Elizabeth Frances Rogers (New Haven: Yale University Press, 1961), p. 130, cited in the following as $S L$.

23. SL, pp. 129-130. The Latin original of this passage is found in The Correspondence of Sir Thomas More, ed. Elizabeth Frances Rogers (Princeton: Princeton University Press, 1947), p. 195.

24. $S L$, p. 90.

25. St. Thomas More, The Confutation of Tyndale's Answer, ed. Louis A. Shuster, Richard C. Marius, James P. Lusardi, and Richard J. Schoeck (New Haven: Yale University Press, 1973), pp. 179 and 1,530 .

26. R. S. Sylvester, "Si Hythlodaeo Credimus: Vision and Revision in Thomas More's Utopia," in Essential Articles for the Study of Thomas More, ed. R. S. Sylvester and G. P. Marc' hadour (Hamden, CT: Archon Books, 1977), p. 297.

27. See note 25 . 